УДК 330

\title{
ПРОБЛЕМЫ ПРЕДСТАВИТЕЛЬСТВА В АРБИТРАЖНОМ ПРОЦЕССЕ
}

\author{
Насыров Рамис Рамильевич \\ студент магистрант \\ Научный руководитель: Скачкова Ольга Сергеевна \\ к.ю.Н., доцент
}

ФГАОУ ВО «Самарский государственный экономический университет»

Аннотация: Статья посвящена отдельным проблемам внедрения института профессионального представительства в арбитражный процесс. Автором изучен зарубежный опыт, исследовано историческое развитие института представительства, проведен анализ мнений ученыхпроцессуалистов относительно возможности введения профессионального представительства в арбитражный процесс, проанализированы правовые позиции Конституционного Суда Российской Федерации с учетом актуальности исследуемого вопроса при рассмотрении корпоративных споров и споров, вытекающих из договоров подряда.

Ключевые слова: право на судебную защиту, доступность правосудия, профессиональное представительство, квалифицированная юридическая помощь.

\section{PROBLEMS OF REPRESENTATION IN THE ARBITRATION PROCESS}

\author{
Nasyrov Ramis Ramilevich \\ Scientific adviser: Skachkova Olga Sergeevna
}

\begin{abstract}
The article is devoted to certain problems of the introduction of the institution of professional representation in the arbitration process. The author has studied foreign experience, studied the historical development of the institution of representation, analyzed the opinions of process scientists on the possibility of introducing professional representation in the arbitration process, analyzed the legal positions of the Constitutional Court of the Russian Federation, taking into account the relevance of the issue under consideration when considering corporate disputes and disputes arising from contract contracts.
\end{abstract}




\section{НАУКА, ОБЩЕСТВО, КУЛЬТУРА: ПРОБЛЕМЫ И ПЕРСПЕКТИВЫ ВЗАИМОДЕЙСТВИЯ В СОВРЕМЕННОМ МИРЕ}

Key words: the right to judicial protection, access to justice, professional representation, qualified legal assistance.

Сегодня соблюдение и гарантии защиты прав и свобод человека являются основой любого демократического общества. Важнейшая роль в этом принадлежит судам. Право на судебную защиту, закрепленное в статье 46 Конституции Российской Федерации, является одним из основных неотчуждаемых прав и свобод граждан, признаваемых и гарантируемых на территории Российской Федерации. Конституционный Суд Российской Федерации, характеризуя право на судебную защиту, рассматривает его не только как одно из конституционных прав человека, но и одновременно как гарантию и средство обеспечения всех других прав и свобод (постановление от 11.05.2005 № 5-П) [1]. Часть 1 статьи 6 Конвенции о защите прав человека и основных свобод гласит: «Каждый в случае спора о его гражданских правах и обязанностях или при предъявлении ему любого уголовного обвинения имеет право на справедливое и публичное разбирательство дела в разумный срок независимым и беспристрастным судом, созданным на основании закона»[2].

Статья 48 Конституции Российской Федерации гарантирует право каждого на получение квалифицированной юридической помощи. Право на получение квалифицированной юридической помощи является неотъемлемой частью права доступа к суду в международном понимании. Конституционный Суд Российской Федерации в постановлении от 19.07.2011 № 17-П указал, что необходимой гарантией судебной защиты и справедливого разбирательства дела является равно предоставляемая сторонам реальная возможность довести свою правовую позицию относительно всех аспектов дела до сведения суда, поскольку только при этом условии в судебном заседании реализуется право на судебную защиту, которая должна быть справедливой, полной и эффективной. С учетом анализа приведенных норм, позиций Конституционного Суда Российской Федерации, можно прийти к выводу о том, что осуществление эффективной судебной защиты и восстановление нарушенных и оспоренных прав, свобод и законных интересов невозможны без оказания эффективной, квалифицированной юридической помощи лицу, обратившемуся в суд за судебной защитой.

Под квалифицированной юридической помощью в научной литературе понимается юридическая деятельность, основанная на нормах международного и внутригосударственного права, а также правилах профессиональной этики 


\section{НАУКА, ОБЩЕСТВО, КУЛЬТУРА: ПРОБЛЕМЫ И ПЕРСПЕКТИВЫ ВЗАИМОДЕЙСТВИЯ В СОВРЕМЕННОМ МИРЕ}

адвоката, осуществляемая на постоянной профессиональной основе, направленная на совершение юридических и фактических действий в целях защиты прав, свобод и законных интересов физических и юридических лиц, обеспечения доступа к правосудию[3].

Квалифицированная юридическая помощь невозможна без профессионального судебного представительства. Следует согласиться с мнением Е.Г. Тарло, который под профессиональным судебным представительством понимает вид деятельности лица, участвующего в процессуальных правоотношениях с целью оказания юридической помощи представляемому участнику процесса, защиты его прав, свобод и законных интересов в пределах полномочий, предоставленных ему соответствующей отраслью процессуального законодательства или процессуальных правил, включенных в отрасли материального права, согласуемых в необходимых случаях с представляемым [5]. Е.В. Салогубова, поддерживая данную точку зрения, под представительством в арбитражном суде понимает деятельность представителя, осуществляемую от имени представляемого с целью добиться для него наиболее благоприятного решения, а также для оказания ему помощи в осуществлении своих прав, предотвращения их нарушения в процессе и оказания арбитражному суду содействия в осуществлении правосудия по делам, отнесенным законом к его ведению [6]. А.О. Гордон, оценивая значение данного института, указывал, что представительство имеет целью удовлетворять настоятельным потребностям жизни. Оно дает возможность отправлять посредством представителей свою юридическую деятельность таким лицам, которые сами не могут этого сделать вследствие каких-либо естественных, юридических или нравственных препятствий (болезнь, отдаленность места деятельности, отсутствие дееспособности, неумение защищать свое дело в суде). Представительство предназначено для уравновешения силы состязающихся в суде сторон[7].

Применительно к арбитражному процессу Конституционный Суд Российской Федерации указал, что государство, допуская в действующей системе правового регулирования возможность выступать в арбитражном суде в качестве представителей организаций штатных сотрудников либо адвокатов, а в качестве представителей граждан - иных, помимо адвокатов, лиц, оказывающих юридическую помощь, тем самым, по существу, не предъявляло особых требований к качеству предоставляемой юридической помощи и, следовательно, не гарантировало ее надлежащего уровня. 


\section{НАУКА, ОБЩЕСТВО, КУЛЬТУРА: ПРОБЛЕМЫ И ПЕРСПЕКТИВЫ ВЗАИМОДЕЙСТВИЯ В СОВРЕМЕННОМ МИРЕ}

С учетом позиции Конституционного Суда Российской Федерации статья 59 АПК РФ в действующей редакции регламентирует возможность граждан вести свои дела в арбитражном суде лично или через представителей. Представителем в арбитражном суде может быть дееспособное лицо с надлежащим образом оформленными и подтвержденными полномочиями на ведение дела. Действующий АПК РФ предусматривает обязательное требование о высшем юридическом образовании представителей. В новой редакции АПК РФ представителями граждан, в том числе индивидуальных предпринимателей, и организаций могут выступать в арбитражном суде адвокаты и иные оказывающие юридическую помощь лица, имеющие высшее юридическое образование. При этом согласно статье 2 Федерального закона 31.05.2002 № 63-Ф3 «Об адвокатской деятельности и адвокатуре в Российской Федерации» адвокатом является независимый профессиональный советник по правовым вопросам. Данные изменения в действующий АПК РФ породили дискуссию среди ученых-процессуалистов. Прежде чем перейти к анализу позиций отечественных ученых относительного данного нововведения, обратимся к зарубежному опыту.

Профессионализм судебных представителей признается важным фактором, влияющим на качество отправления правосудия, и поэтому ему уделяется серьезное внимание во многих государствах, принадлежащих к различным судебным системам. Подробно проанализировал зарубежный опыт по данному вопросу А.А. Соловьев, который пришел к выводу о том, что общий подход законодательного регулирования зарубежных стран заключается в том, что представительство в суде без адвоката в принципе возможно, однако в весьма ограниченном числе случаев. Так, в подавляющем большинстве судов США только адвокаты могут выполнять функции представителей в судебном процессе. Есть, однако, и некоторые исключения. В некоторых судах низшей инстанции, особенно на Западе США, стороны могут иметь в качестве своих представителей лиц, не являющихся адвокатами[8]. Согласно законодательству Французской Республики представительство и помощь в суде по общему правилу осуществляется адвокатами, для чего действует система послевузовской профессиональной подготовки лиц, претендующих на получение статуса адвоката. В Швейцарии в качестве адвокатов в Федеральном суде также могут выступать только профессиональные адвокаты или профессора-правоведы швейцарских университетов. 


\section{НАУКА, ОБЩЕСТВО, КУЛЬТУРА: ПРОБЛЕМЫ И ПЕРСПЕКТИВЫ ВЗАИМОДЕЙСТВИЯ В СОВРЕМЕННОМ МИРЕ}

Германии адвокат осуществляет свободную профессиональную деятельность, являясь независимым советником и представителем интересов сторон во всех делах.

В России, с учетом опыта исторического развития института представительства, позиции ученых относительно требования о высшем юридическом образовании представителей диаметрально противоположны. Так, Е.В. Васьковский писал о необходимости равного участия сторон в процессе. По его мнению, принцип состязательности надлежит признать эффективным только в том случае, когда стороны одинаково подготовлены к процессуальной борьбе. При данных условиях суд остается независимым наблюдателем, который должен определить, какая сторона выиграла дело. Напротив, неравенство сторон, в частности, в знании юриспруденции, в образовании является препятствием к торжеству справедливости. В качестве примера автор приводил процессуальную борьбу профессионального адвоката, «до тонкости изучившего все приемы и средства процессуальной борьбы», и человека, не обладающего юридическими познаниями и являющегося «совершенным новичком в процессе»[9].

Е.А. Борисова, поддерживая указанную позицию, ссылается на цитату Уполномоченного по правам человека в Хабаровском крае: «...все жители края не могут быть практикующими юристами, владеющими нюансами процессуального законодательства. Особенно трудно получить доступ к правосудию социально уязвимым гражданам, прежде всего - пенсионерам и инвалидам. Из-за слабого материального положения они не могут прибегнуть к помощи юристов при составлении исковых заявлений, а излишние эмоции мешают человеку спокойно составить иск. В итоге требования, предъявляемые законодательством к исковым заявлениям, создают серьезные препятствия при реализации гражданами своих прав на судебную защиту»[10].

T.Е. Абова приводит пример, когда высказываются соображения о том, что суд должен помогать реализовать процессуальные права стороне, не обладающей возможностью защитить себя с помощью юридически грамотного представителя в споре с сильным в этом отношении противником. В подобной ситуации нарушается принцип процессуального равноправия сторон. Не суд, а государство должно позаботиться о том, чтобы его граждане имели возможность получить за минимальную плату (или даже бесплатно) юридически грамотного помощника для ведения дела в суде[11]. 


\section{НАУКА, ОБЩЕСТВО, КУЛЬТУРА: ПРОБЛЕМЫ И ПЕРСПЕКТИВЫ ВЗАИМОДЕЙСТВИЯ В СОВРЕМЕННОМ МИРЕ}

Таким образом, позиции отечественных ученых, поддерживающих введение требования об обязательном участии в арбитражном процессе профессионального представителя, сводятся к тому, что введение данного института уравновешивает позиции сторон, способствовует развитию состязательных начал в цивилистическом процессе, является барьером попыткам злоупотребления граждан и организаций правом на обращение в суд, а также другим злоупотреблениям процессуальными правами в ходе судебного разбирательства.

Между тем ряд ученых придерживаются противоположной позиции. Так, например, Е.Р. Русинова говорит о преждевременности введения требования о наличии высшего юридического образования у представителей, поскольку в настоящее время доступность субсидируемой бесплатной юридической помощи ограничена в силу финансовых и организационных причин[12]. Критикуя введение профессионального представительства в судебный процесс, И.М. Дивин указал, что наличие диплома о высшем юридическом образовании не свидетельствует о высоком профессионализме лица, желающего осуществлять судебное представительство.

По мнению Л.В. Тумановой, такой формальный критерий, как наличие высшего юридического образования или ученой степени в сфере права, а также наличие адвокатского статуса, не дает реальной гарантии оказания квалифицированной юридической помощи[13]. Относительно данного вопроса Конституционный Суд Российской Федерации также высказывал ряд правовых позиций. Так, в определениях от 24.11.2016 № 2559-О и от 27.09.2016 № 1782-О Конституционный Суд Российской Федерации указал, что: - конституционное право на судебную защиту и принципы состязательности и равноправия сторон не предполагают выбор по своему усмотрению любых способов и процедур судебной защиты; - право вести свои дела в суде через самостоятельно выбранного представителя не означает безусловное право выбирать в качестве такового любое лицо и не предполагает возможность участия в судопроизводстве любого лица в качестве представителя; - установление критериев квалифицированной юридической помощи и обусловленных ими особенностей и условий допуска тех или иных лиц в качестве защитников или представителей в конкретных видах судопроизводства является прерогативой законодателя. Из приведенных правовых позиций усматривается, что законодательное введение института профессионального представительства зависит от конкретного вида судопроизводства и категорий дел, которые рассматриваются судом. 


\section{НАУКА, ОБЩЕСТВО, КУЛЬТУРА: ПРОБЛЕМЫ И ПЕРСПЕКТИВЫ ВЗАИМОДЕЙСТВИЯ В СОВРЕМЕННОМ МИРЕ}

В некоторых случаях действия/бездействия сторон обусловлены не мотивами, направленными на злоупотребление процессуальными правами и обязанностями, а отсутствием специальных юридических познаний, позволяющих своевременно и правильно осуществить процессуальное действие. При рассмотрении дел, требования по которым вытекают из договоров подряда, суд сталкивается с непрофессиональными действиями представителей еще на стадии проверки соблюдения обязательного досудебного порядка урегулирования спора, предусмотренного договором, а при его отсутствии в договоре - частью 5 статьи 4 АПК РФ. В данном случае, имеет место некорректная формулировка просительной части претензии, и ее мотивировочная часть требует дополнительных пояснений. В последующем это влечет несоответствие содержания претензии исковым требованиям. При этом сами представители в заседании, признавая названные выше недостатки, указывают на свой непрофессионализм в области права.

C учетом возрастающего с каждым годом доверия к суду, a, следовательно, количества дел, возросшей нагрузки, а также кадрового дефицита работников аппарата судов, названные выше непрофессиональные действия представителей лиц, участвующих в деле, приводят, в результате, к большим временным трудозатратам как судей (принятие иска к производству, проведение заседания), так и отдела судьи (формирование дела, отправка корреспонденции, изготовление справок на возврат государственной пошлины и т.д.), которых можно было избежать, если бы дело вели профессиональные представители.

Таким образом, с учетом специфики категорий споров, рассматриваемых арбитражными судами, введение института профессионального представительства стало необходимым в целях оптимизации судебного процесса, сокращения процессуальных сроков рассмотрения дел, а также обеспечения лиц, участвующих в деле, всем объемом процессуальных гарантий права на судебную защиту, предусмотренных Конституцией Российской Федерации и АПК РФ. Теперь, чтобы выступить в роли представителя, гражданину необходимо иметь высшее юридическое образование либо ученую степень по юридической специальности. Исключение составляют законные представители организаций (например, лицо, занимающее должность генерального директора), а также патентные поверенные по спорам об охране интеллектуальной собственности, арбитражные управляющие в делах о банкротстве. Такое нововведение, с одной стороны, ограничивает доступ 


\section{НАУКА, ОБЩЕСТВО, КУЛЬТУРА: ПРОБЛЕМЫ И ПЕРСПЕКТИВЫ ВЗАИМОДЕЙСТВИЯ В СОВРЕМЕННОМ МИРЕ}

некомпетентных лиц к судопроизводству. А с другой - вынуждает граждан осуществлять поиск юристов, кандидатов или докторов юридических наук и, как правило, за дополнительную плату. К тому же данное требование не одинаково справедливо для физических лиц и для представителей юридических лиц, имеющие право защищать интересы своей компании в прежнем порядке, т.е. не имея знаний по юридической специальности. Повышение требований к квалификации представителей в арбитраже может повлечь за собой рост стоимости юридических услуг в целом.

\section{Список литературы}

1. Гагиев А.К. Доступность конституционного правосудия для граждан // Журнал конституционного правосудия. - 2019. - №3 (45) // СПС «КонсультантПлюс».

2. Конвенция о защите прав человека и основных свобод (заключена в г. Риме 04.11.1950) // СПС «КонсультантПлюс».

3. Халеппо E.M. Правовое положение адвоката как участника гражданского и арбитражного процесса в Российской Федерации: Автореф. дис. ... канд. юрид. наук. - М., 2019. - С. 9.

4. Тарло Е.Г. Проблемы профессионального представителя в судопроизводстве России: автореф. дис. ... д-ра юр. наук. - М., 2019. - С. 7.

5. Арбитражный процесс: учебник для студентов юридических вузов и факультетов. - 5-е изд., перераб. и доп. / под ред. М.К. Треушникова. - М.: Городец, 2019. - С. 154-155.

6. См.: Гордон А.О. Представительство в гражданском праве. - С.-Пб.: Типография Шредера, 1879. - С. 7-8.

7. См.: Энгельман И.Е. Курс русского гражданского судопроизводства. Изд. 3-е, испр. и доп. - Юрьев: Типография К. Маттисена, 1912. - С. 159-160.

8. Терела Е.А. Современная адвокатура Франции // Актуальные проблемы российского права. - 2007. - № 1. С. 660.

9. См.: Васьковский Е.В. Курс гражданского процесса: Субъекты и объекты процесса, процессуальные отношения и действия. - М.: Статут, 2018. C. 364 .

10. Борисова Е.А. Проблемы реализации права на судебную защиту в гражданском и административном судопроизводстве // Вестник гражданского процесса. - 2018. - № 1 // СПС «КонсультантПлюс». 
11. Абова Т.Е. Обеспечение физическим и юридическим лицам права на судебную защиту // Материалы Всероссийской научно-практической конференции, Москва 31 января - 1 февраля 2001. - М.: Лиджист, 2018.

12. Русинова Е.Р. Некоторые размышления о реформе процессуального законодательства с точки зрения принципа доступности судебной защиты // Арбитражный и гражданский процесс. - 2017. - № 12 // СПС «КонсультантПлюс».

13. Туманова Л.В. Некоторые вопросы представительства в гражданском судопроизводстве // Арбитражный и гражданский процесс. - 2019. - № 3 // СПС «КонсультантПлюс» 